\title{
KAJIAN METODE KOAGULASI PADA PENGOLAHAN AIR SUMUR MENGANDUNG TIMBAL BERVALENSI II DI KOTA PASURUAN
}

\author{
Esthi Kusdarini \\ Jurusan Teknik Pertambangan Institut Teknologi Adhi Tama Surabaya (ITATS), \\ Surabaya, Indonesia \\ E-mail: esthi_kusdarini@yahoo.com
}

\begin{abstract}
One of the major needs in human life is water. Some communities in the town of Pasuruan still use well water for cooking and drinking. Based on previous studies it is known that five samples of well water in the town of Pasuruan containing Pb above the maximum limit water requirements based on Regulation of the Minister of Health Nomor 416/MENKES/PER/IX/1990. One of simple method that can reduce the content of $\mathrm{Pb}$ metal in water is coagulation. The purposes of this research are: 1) to get some kinds of coagulants which could reduce $\mathrm{Pb}$ metal; 2) to obtain a coagulant efficiency; 3) to recommend coagulant which can be used to process well water containing $\mathrm{Pb}$. This research was using quantitative descriptive technique by collecting data from the study of literature. The research is done in four stages: 1) looked for the laboraturium analysis result of well water samples; 2) comparing the results of the analysis to the requirements of clean water; 3) looking coagulant that can be used to reduce the content of $\mathrm{Pb}$ in water; 4) assessed the efficiency of coagulants. The results showed that: 1) the coagulants that can be used to reduce the content of $P b$ are: $a$ ) sea water; b) Moringa seed powder; c) powdered activated hyacinth 2\%; d) alum $20 \mathrm{mg} / \mathrm{L}$ and $1250 \mathrm{mg} / \mathrm{L}$; e) $\mathrm{FeCl}_{3}$; 2) the efficiency of coagulant sea water reached 95.5\%, Moringa seed powder reaches $95.6 \%$, powder activated hyacinth reached 96\%; alum $20 \mathrm{mg} / \mathrm{L}$ reached 36\%, alum $1250 \mathrm{mg} / \mathrm{L} \mathrm{at} 67 \% ; \mathrm{FeCl}_{3}$ reached $84 \%$; 3) The coagulants that can be used to process five sample wells are seawater, Moringa seed powder, powdered activated hyacinth $2 \% \mathrm{NaOH}$, dan $\mathrm{FeCl}_{3} 1000 \mathrm{mg} / \mathrm{L}$.
\end{abstract}

Keywords: clean, Pasuruan, $\mathrm{Pb}$, water, well

\begin{abstract}
ABSTRAK
Salah satu kebutuhan utama dalam kehidupan manusia adalah air bersih. Sebagian masyarakat kota Pasuruan masih menggunakan air sumur untuk masak dan minum. Berdasarkan penelitian sebelumnya diketahui bahwa lima sampel air sumur di kota Pasuruan mengandung logam $\mathrm{Pb}$ di atas batas maksimum persyaratan air bersih berdasarkan Peraturan Menteri Kesehatan Nomor 416/MENKES/PER/IX/1990. Salah satu metode sederhana yang bisa menurunkan kandungan logam $\mathrm{Pb}$ dalam air adalah koagulasi. Tujuan penulisan adalah : 1) mendapatkan data koagulan yang bisa menurunkan kandungan logam $\mathrm{Pb} ; 2$ ) memperoleh efisiensi koagulan; 3) merekomendasikan koagulan yang bisa digunakan untuk mengolah air sumur mengandung logam $\mathrm{Pb}$. Penulisan ini menggunakan metode deskriptif kuantitatif dengan pengambilan data dari studi kepustakaan. Penulisan dilakukan dalam empat tahap : 1) mencari data hasil analisa laboratorium sampel air sumur; 2) membandingkan hasil analisa dengan persyaratan air bersih; 3) mencari koagulan yang bisa digunakan untuk menurunkan kandungan logam $\mathrm{Pb}$ dalam air; 4) mengkaji efisiensi koagulan. Hasil kajian menunjukkan bahwa : 1) koagulan yang bisa digunakan untuk menurunkan kandungan logam $\mathrm{Pb}$ adalah : a) air laut; b) serbuk biji kelor; c) serbuk eceng gondok teraktivasi 2\%; d) alum $20 \mathrm{mg} / \mathrm{L}$ dan $1250 \mathrm{mg} / \mathrm{L}$; e) $\mathrm{FeCl}_{3}$; 2) efisiensi koagulan air laut mencapai 95,5\%, serbuk biji kelor mencapai 95,6\%, serbuk eceng gondok teraktivasi mencapai $96 \%$; alum $20 \mathrm{mg} / \mathrm{L}$ mencapai $36 \%$, alum 1250 $\mathrm{mg} / \mathrm{L}$ mencapai $67 \%$; $\mathrm{FeCl}_{3}$ mencapai 84\%; 3) koagulan yang bisa digunakan untuk mengolah lima sampel sumur adalah air laut, serbuk biji kelor, serbuk eceng gondok teraktivasi $\mathrm{NaOH} 2 \%$, dan $\mathrm{FeCl}_{3} 1000 \mathrm{mg} / \mathrm{L}$.
\end{abstract}

Kata kunci: air, bersih, Pasuruan, $\mathrm{Pb}$, sumur

\section{PENDAHULUAN}

Air bersih merupakan kebutuhan utama bagi kehidupan manusia. Kualitas kehidupan manusia bisa dilihat dari air bersih yang digunakan. Berdasarkan penelitian yang dilakukan pada 
bulan Juni 2015 yang berlokasi di kecamatan Panggungrejo dan Purworejo kota Pasuruan Provinsi Jawa Timur, terdapat lima sampel air sumur mengandung logam $\mathrm{Pb}$. Kandungan logam $\mathrm{Pb}$ dalam air sampel sebesar $0,15 \mathrm{mg} / \mathrm{L}$ sampai $0,23 \mathrm{mg} / \mathrm{L}$ [1]. Sedangkan batas maksimum yang diperbolehkan sebesar $0,05 \mathrm{mg} / \mathrm{L}$ [2]. Sebagian masyarakat masih menggunakan air sumur untuk masak dan minum. Kadar $\mathrm{Pb}$ yang melebihi ambang batas akan membahayakan kesehatan manusia yang mengkonsumsinya. Logam $\mathrm{Pb}$ akan terakumulasi dalam tubuh manusia. Kadar $\mathrm{Pb}$ yang terakumulasi dalam tubuh manusia bisa melebihi kadar $\mathrm{Pb}$ dalam air sumur. Berdasarkan fakta bahwa logam $\mathrm{Pb}$ sangat berbahaya maka air sumur harus diolah dahulu sebelum digunakan untuk masak dan minum.

Kandungan logam $\mathrm{Pb}$ yang tinggi dalam air dapat diturunkan dengan koagulasi. Beberapa peneliti sudah mencari efisiensi beberapa koagulan yang bisa digunakan untuk menurunkan kandungan logam $\mathrm{Pb}$ dalam air. Efisiensi koagulan, harga koagulan, biaya pengoperasian, dan kemudahan pengoperasian merupakan faktor penting dalam pemilihan koagulan. Penelitian ini akan mengkaji beberapa koagulan yang telah diteliti dalam menurunkan kandungan logam $\mathrm{Pb}$ dalam air. Data dari beberapa penelitian ini masih terpisah-pisah. Oleh karena itu sangatlah penting untuk memetakan penelitian-penelitian yang sudah dilakukan. Hasil pemetaan ini akan menunjukkan jenis-jenis koagulan yang cukup efektif dan efisien menurunkan kandungan logam $\mathrm{Pb}$ dalam air. Penelitian ini akan sangat membantu masyarakat yang masih mengkonsumsi air sumur mengandung $\mathrm{Pb}$ untuk keperluan masak dan minum.

\section{TINJAUAN PUSTAKA}

Sumber air sumur pada umumnya berasal dari air tanah dangkal. Air tanah dapat digolongkan menjadi air tanah dangkal $(0-40 \mathrm{~m})$ dan air tanah dalam $(>40 \mathrm{~m})$. Sumur bor milik warga di kota Pasuruan ini rata-rata mempunyai kedalaman $12 \mathrm{~m}$, yang berarti memanfaatkan sumber air tanah dangkal. Air bisa digunakan untuk masak dan minum bila memenuhi persyaratan kesehatan, baik dari segi fisik, kimiawi, mikrobiologis dan radioaktivitas. Logam $\mathrm{Pb}$ merupakan bahan pencemar kimiawi. Keberadaannya dalam air perlu diperhatikan karena pada kadar tertentu dapat membahayakan kesehatan manusia yang mengkonsumsinya. Logam $\mathrm{Pb}$ merupakan zat anorganik sehingga tidak dapat dihancurkan melalui degradasi biologi seperti bahan pencemar organik. Logam $\mathrm{Pb}$ cenderung terakumulasi dalam jaringan tubuh.

Logam berat $\mathrm{Pb}$ dapat masuk ke dalam sumber air melalui beberapa sebab, antara lain :

1. Air permukaan tercemar logam berat $\mathrm{Pb}$ dan meresap ke dalam air tanah.

2. Limbah industri atau limbah rumah tangga yang mengandung logam $\mathrm{Pb}$ meresap ke dalam air tanah.

3. Leaching logam berat $\mathrm{Pb}$ dari tempat pembuangan sampah meresap ke air tanah.

4. Air permukaan yang asam melarutkan logam berat $\mathrm{Pb}$ yang terkandung dalam tanah.

Secara garis besar logam $\mathrm{Pb}$ dan persenyawaannya yang terkandung dalam air sumur disebabkan dua hal, yaitu ada secara alamiah atau ada sebagai dampak dari aktifitas manusia. Secara alamiah, $\mathrm{Pb}$ dapat meresap ke dalam air tanah melalui pengkristalan $\mathrm{Pb}$ di udara dengan bantuan air hujan. Selain itu, proses korosifikasi dari batuan mineral akibat hempasan gelombang dan angin, juga merupakan salah satu jalur sumber $\mathrm{Pb}$ yang akan meresap ke dalam air tanah.

Selanjutnya logam berat $\mathrm{Pb}$ juga bisa meresap ke dalam air tanah sebagai dampak dari aktifitas kehidupan manusia. Buangan limbah industri yang mengandung $\mathrm{Pb}$, seperti limbah industri kertas, baterai, perakitan peralatan elektronik, cat, sisa dari pertambangan bijih timah hitam, dan lindi dari TPA sampah juga bisa meresap ke dalam air tanah. Buangan limbah industri yang berada di permukaan tanah akan meresap ke dalam air tanah bila terjadi hujan atau terbawa aliran air. Selanjutnya air yang membawa bahan pencemar masuk ke dalam air tanah. Semakin tinggi nilai porositas dan permeabilitas tanah, semakin tinggi kecepatan aliran air yang membawa bahan pencemar masuk ke dalam air tanah. 


\section{Dampak Kandungan Logam Berat Pb dalam Air Sumur}

Kandungan logam $\mathrm{Pb}$ dalam air sumur yang melebihi baku mutu air bersih akan membahayakan kesehatan manusia yang menggunakannya. Logam $\mathrm{Pb}$ bisa menghambat aktivitas enzim yang terlibat dalam pembentukan hemoglobin $(\mathrm{Hb})$. Sebagian kecil logam $\mathrm{Pb}$ akan dikeluarkan lewat urin atau feses karena sebagian terikat oleh protein. Sedangkan sisanya akan terakumulasi dalam ginjal, hati, kuku, jaringan lemak dan rambut.

Timbal merupakan logam berat yang bersifat toksik meskipun dalam konsentrasi yang rendah. Logam berat dapat terakumulasi pada tubuh manusia dan bersifat bioakumulasi. Hal ini mengakibatkan kadar $\mathrm{Pb}$ dalam tubuh manusia lebih tinggi dibandingkan dengan kadar $\mathrm{Pb}$ dalam air sumur yang dikonsumsi oleh warga. Kandungan logam $\mathrm{Pb}$ yang tinggi pada tubuh manusia dapat mempendek umur sel darah merah hingga menderita anemia, menyebabkan gangguan metabolisme zat besi dan sintesis globin dalam sel darah merah, menghambat aktivitas berbagai enzim serta gangguan pada sistem pencernaan, ginjal dan sistem saraf pusat [3].

Paparan $\mathrm{Pb}$ secara kronis dapat menimbulkan kelelahan, kelesuan, gangguan iritabilitas, gangguan gastrointestinal, kehilangan libido, infertilitas pada laki-laki, gangguan menstruasi serta aborsi spontan pada wanita dan teratospermia [4]. Paparan $\mathrm{Pb}$ juga dapat menyebabkan ostereoporosis pada wanita. Pada sistem aliran darah $\mathrm{Pb}$ yang diserap akan mengendap di tulang dan bergabung dengan matrik tulang. Tulang yang mengandung $\mathrm{Pb}$ akan naik katabolismenya sehingga konsentrasi $\mathrm{Pb}$ dalam sirkulasi darah juga meningkat. Kondisi ini dapat menyebabkan timbulnya berbagai penyakit seperti hipertiroidisme dan ostereoporosis [5].

\section{Koagulasi untuk Menurunkan Kandungan Logam Pb dalam Air Sumur}

Beberapa metode untuk menurunkan kandungan logam $\mathrm{Pb}$ dalam air antara lain koagulasi, kation exchanger, adsorpsi, dan bioremediasi. Penelitian ini akan membahas salah satu dari metode tersebut. Pembahasan akan difokuskan pada metode koagulasi. Koagulasi adalah proses yang dilakukan untuk mengubah partikel-partikel kecil menjadi bentuk flok (partikel yang lebih besar). Koagulasi mampu menyerap polutan/pencemar, seperti logam berat, zat organik, dan zat pencemar yang lain. Sedangkan flokulasi adalah proses terbentuknya penggumpalan flok-flok yang lebih besar dan akibat adanya perbedaan berat jenis terhadap air, maka flok-flok dengan mudah mengendap di bak sedimentasi. Logam berat timbal $(\mathrm{Pb})$ di dalam air dapat dihilangkan dengan cara pengendapan sebagai sulfida dan karbonat pada $\mathrm{pH} 7,5-8,5$. Timbal Karbonat $\left(\mathrm{PbCO}_{3}\right)$ cenderung membentuk endapan sebagai kristal dibandingkan dengan timbal hidroksida $\left(\mathrm{Pb}(\mathrm{OH})_{2}\right)$ sehingga lebih mudah dilakukan penyaringan [6]. Koagulan yang digunakan bisa berupa koagulan alami ataupun kimiawi. Koagulan alami misalnya biji kelor, air laut, biji trembesi, biji asam jawa, biji kacang merah, dan sebagainya. Sedangkan koagulan kimiawi misalnya tawas/alum, PAC, lime, ferri klorida, ferri sulfat, dan sebagainya.

\section{METODE}

Metode penelitian yang digunakan dalam penelitian ini adalah deskriptif kuantitatif. Data diperoleh dari penelitian sebelumnya. Penelitian dilakukan dalam empat tahap, yaitu : 1) mencari data hasil analisa laboratorium lima sampel air sumur dari penelitian terdahulu; 2) membandingkan hasil analisa dengan syarat air bersih [2]; 3) mencari beberapa jenis koagulan yang bisa digunakan untuk menurunkan kandungan logam $\mathrm{Pb}$ dalam air; 4) mengkaji efisiensi koagulan yang sudah diteliti berdasarkan studi terdahulu.

\section{HASIL DAN PEMBAHASAN}

Berdasarkan penelitian yang telah dilakukan, terdapat lima sumur yang mengandung logam $\mathrm{Pb}$ melebihi batas maksimum persyaratan air bersih [1]. Lokasi dari lima sumur tersebut berturutturut adalah : Kelurahan Kebonagung kecamatan Purworejo, Kelurahan Purworejo kecamatan Purworejo, Kelurahan Bangilan kecamatan Panggungrejo, Kelurahan Trajeng kecamatan Panggungrejo, Kelurahan Bugul Lor kecamatan Panggungrejo. 
Kandungan logam pada masing-masing sampel air sumur dapat dilihat pada Tabel 1 sampai Tabel 5 .

Tabel 1. Kandungan logam berat pada sampel air sumur di kelurahan Kebonagung kecamatan Purworejo

\begin{tabular}{cccl}
\hline Cadmium $(\mathrm{Cd})$ & $\begin{array}{c}\text { Kandungan } \\
(\mathrm{ppm})\end{array}$ & $\begin{array}{c}\text { Standard* } \\
(\mathrm{ppm})\end{array}$ & Keterangan \\
\hline \hline Arsen $(\mathrm{As})$ & $<0,00004$ & 0.05 & memenuhi standard \\
Besi $(\mathrm{Fe})$ & $<0,004$ & 1 & memenuhi standard \\
Cadmium $(\mathrm{Cd})$ & $<0,001$ & 0.005 & memenuhi standard \\
Kromium $(\mathrm{VI})$ & 0.01 & 0.05 & memenuhi standard \\
Mangan $(\mathrm{Mn})$ & 0.23 & 0.5 & memenuhi standard \\
Air raksa $(\mathrm{Hg})$ & $<0,000002$ & 0.001 & memenuhi standard \\
Selenium $(\mathrm{Se})$ & $<0,00003$ & 0.01 & memenuhi standard \\
Timbal $(\mathrm{Pb})$ & 0.23 & 0.05 & tidak memenuhi standard \\
\hline \hline
\end{tabular}

Keterangan : * Berdasarkan Permenkes/416/MENKES/PER/IX/1990 [2]

Sumber : Hasil analisa laboratorium, 2015 [1]

Tabel 2. Kandungan logam berat pada sampel air sumur di kelurahan Purworejo kecamatan Purworejo

\begin{tabular}{cccc}
\hline Cadmium $(\mathrm{Cd})$ & $\begin{array}{c}\text { Kandungan } \\
(\mathrm{ppm})\end{array}$ & $\begin{array}{c}\text { Standard* } \\
(\mathrm{ppm})\end{array}$ & Keterangan \\
\hline \hline Arsen $(\mathrm{As})$ & $<0,00004$ & 0.05 & memenuhi standard \\
Besi $(\mathrm{Fe})$ & $<0,004$ & 1 & $\begin{array}{l}\text { memenuhi standard } \\
\text { memenuhi standard }\end{array}$ \\
Cadmium $(\mathrm{Cd})$ & $<0,001$ & 0.005 & memenuhi standard \\
Kromium $(\mathrm{VI})(\mathrm{Cr}$ & & 0.05 & memenuhi standard \\
$(\mathrm{VI}))$ & 0,008 & 0.5 & memenuhi standard \\
Mangan $(\mathrm{Mn})$ & 0.06 & 0.001 & memenuhi standard \\
Air raksa $(\mathrm{Hg})$ & $<0,000002$ & 0.01 & tidak memenuhi standard \\
Selenium $(\mathrm{Se})$ & $<0,00003$ & 0.05 & \\
Timbal $(\mathrm{Pb})$ & 0,15 & &
\end{tabular}

Sumber : Hasil analisa laboratorium, 2015 [1]

Tabel 3. Kandungan logam berat pada sampel air sumur di kelurahan Bangilan kecamatan Panggungrejo

\begin{tabular}{cccc}
\hline $\mathrm{C}$ & $\begin{array}{c}\text { Kandungan } \\
(\mathrm{ppm})\end{array}$ & $\begin{array}{c}\text { Standard* } \\
(\mathrm{ppm})\end{array}$ & Keterangan \\
\hline \hline Arsen $(\mathrm{As})$ & $<0,00004$ & 0.05 & memenuhi standard \\
Besi $(\mathrm{Fe})$ & $<0,004$ & 1 & memenuhi standard \\
Cadmium $(\mathrm{Cd})$ & $<0,001$ & 0.005 & memenuhi standard \\
Kromium $(\mathrm{VI})(\mathrm{Cr}$ & & 0.05 & memenuhi standard \\
$(\mathrm{VI}))$ & 00,001 & 0.5 & memenuhi standard \\
Mangan $(\mathrm{Mn})$ & 0.16 & 0.001 & memenuhi standard \\
Air raksa $(\mathrm{Hg})$ & $<0,000002$ & 0.01 & memenuhi standard \\
Selenium $(\mathrm{Se})$ & $<0,00003$ & 0.05 & tidak memenuhi standard \\
Timbal $(\mathrm{Pb})$ & 0,16 & &
\end{tabular}

Sumber : Hasil analisa laboratorium, 2015 [1] 
Tabel 4. Kandungan logam berat pada sampel air sumur di kelurahanTrajeng kecamatan Panggungrejo

\begin{tabular}{cccc}
\hline Cadmium $(\mathrm{Cd})$ & $\begin{array}{c}\text { Kandungan } \\
(\mathrm{ppm})\end{array}$ & $\begin{array}{c}\text { Standard* } \\
(\mathrm{ppm})\end{array}$ & Keterangan \\
\hline \hline Arsen $(\mathrm{As})$ & $<0,00004$ & 0.05 & memenuhi standard \\
Besi $(\mathrm{Fe})$ & $<0,004$ & 1 & memenuhi standard \\
Cadmium $(\mathrm{Cd})$ & $<0,001$ & 0.005 & memenuhi standard \\
Kromium $(\mathrm{VI})(\mathrm{Cr}$ & & 0.05 & memenuhi standard \\
(VI)) & 0,01 & 0.5 & memenuhi standard \\
Mangan $(\mathrm{Mn})$ & 0,09 & 0.001 & memenuhi standard \\
Air raksa $(\mathrm{Hg})$ & $<0,000002$ & 0.01 & memenuhi standard \\
Selenium $(\mathrm{Se})$ & $<0,00003$ & 0.05 & tidak memenuhi standard \\
Timbal $(\mathrm{Pb})$ & 0,16 & &
\end{tabular}

Sumber : Hasil analisa laboratorium, 2015 [1]

Tabel 5. Kandungan logam berat pada sampel air sumur di kelurahan Bugul Lor kecamatan Panggungrejo

\begin{tabular}{cccc}
\hline Cadmium $(\mathrm{Cd})$ & $\begin{array}{c}\text { Kandungan } \\
(\mathrm{ppm})\end{array}$ & $\begin{array}{c}\text { Standard* } \\
(\mathrm{ppm})\end{array}$ & Keterangan \\
\hline \hline Arsen $(\mathrm{As})$ & $<0,00004$ & 0.05 & memenuhi standard \\
Besi $(\mathrm{Fe})$ & $<0,004$ & 1 & memenuhi standard \\
Cadmium $(\mathrm{Cd})$ & $<0,001$ & 0.005 & memenuhi standard \\
Kromium $(\mathrm{VI})(\mathrm{Cr}$ & $<0,001$ & 0.05 & memenuhi standard \\
$(\mathrm{VI}))$ & $<0,002$ & 0.5 & memenuhi standard \\
Mangan $(\mathrm{Mn})$ & $<0,000002$ & 0.001 & memenuhi standard \\
Air raksa $(\mathrm{Hg})$ & $<0,00003$ & 0.01 & memenuhi standard \\
Selenium $(\mathrm{Se})$ & 0,16 & 0.05 & tidak memenuhi standard \\
Timbal $(\mathrm{Pb})$ & & & \\
\hline \hline
\end{tabular}

Sumber : Hasil analisa laboratorium, 2015 [1]

Berdasarkan Tabel 1 sampai Tabel 5 kandungan Arsen, Besi, Fluor, Cadmium, Kromium (VI), Mangan, Air Raksa, dan Selenium dalam air sumur sudah memenuhi persyaratan air bersih. Akan tetapi kandungan Timbal $(\mathrm{Pb})$ masih di atas batas maksimum yang diperbolehkan berdasarkan PERMENKES Nomor 416/MENKES/PER/IX/1990. Kandungan logam Pb pada kelima sampel air sumur disajikan pada Gambar 1. 


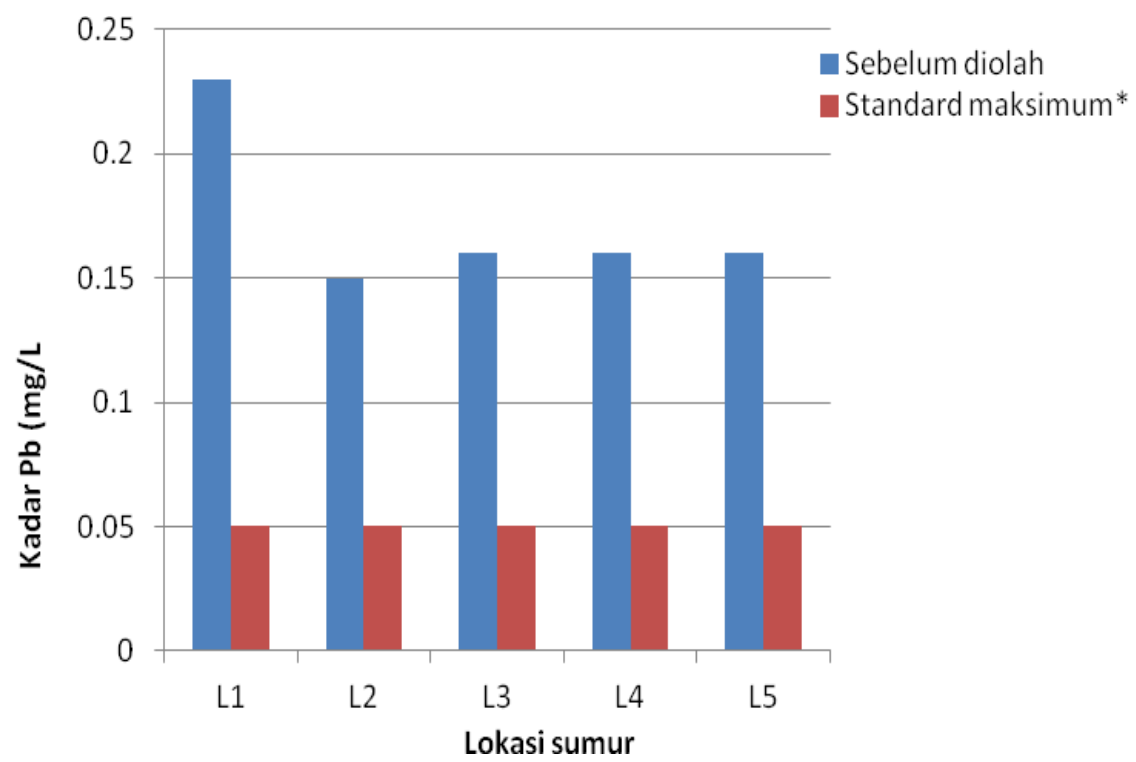

Gambar 1. Kandungan Pb pada 5 sampel air sumur di daerah Pasuruan dibandingkan dengan standard maksimum air bersih

Keterangan gambar :

L1 : Kelurahan Kebonagung kecamatan Purworejo

L2 : Kelurahan Purworejo kecamatan Purworejo

L3 : Kelurahan Bangilan kecamatan Panggungrejo

L4 : Kelurahan Trajeng kecamatan Panggungrejo

L5 : Kelurahan Bugul Lor kecamatan Panggungrejo

*sesuai persyaratan air bersih [2]

Berdasarkan Gambar 1, kadar Pb pada kelima sampel air sumur masih di atas batas maksimum yang diperbolehkan [2]. Oleh karena itu kandungan $\mathrm{Pb}$ dalam air sumur ini harus diturunkan agar bisa digunakan untuk masak dan bahan baku air minum. Beberapa koagulan bisa digunakan untuk menurunkan kandungan $\mathrm{Pb}$ dalam air sumur. Koagulan ini bisa merupakan koagulan alami maupun kimiawi. Kajian ini akan membandingkan efisiensi beberapa koagulan yang sudah diteliti untuk menurunkan kandungan $\mathrm{Pb}$ dalam air. Rumus yang digunakan untuk menghitung effisiensi seperti pada persamaan (1) [7].

$$
\text { Efisiensi }(\%)=\left(\frac{C_{i}-C_{t}}{C_{i}}\right) \times 100 \%
$$

Dimana : $\quad \mathrm{C}_{\mathrm{i}}=$ kadar $\mathrm{Pb}$ sebelum diolah $(\mathrm{mg} / \mathrm{L})$

$\mathrm{C}_{\mathrm{t}}=$ kadar $\mathrm{Pb}$ setelah diolah $(\mathrm{mg} / \mathrm{L})$

\section{Koagulasi Menggunakan Koagulan Alami}

Beberapa koagulan alami telah diteliti untuk menurunkan kandungan logam $\mathrm{Pb}$. Ion $\mathrm{Pb}^{2+}$ yang terdapat dalam air bisa dihilangkan dengan koagulan yang mengandung anion sehingga diharapkan ion $\mathrm{Pb}^{2+}$ akan berikatan dengan anion dalam koagulan. Koagulan alami yang sudah diteliti antara lain air laut, serbuk biji kelor, serbuk eceng gondok teraktivasi $\mathrm{NaOH} 2 \%$.

\section{Air Laut}

Penelitian dengan memanfaatkan air laut sebagai koagulan untuk mengolah air sumur mengandung logam $\mathrm{Pb}$ telah dilakukan di sekitar TPA Jatibarang, Semarang [8]. Air laut mengandung garam-garaman seperti $\mathrm{NaCl}$ dan sulfat [9]. Reaksi yang terjadi pada proses koagulasi ini adalah 


$$
\begin{array}{lll}
\mathrm{Pb}^{2+}+2 \mathrm{Cl}^{-} & \longrightarrow & \mathrm{PbCl}_{2} \\
\mathrm{~Pb}^{2+}+\mathrm{SO}_{4}^{2-} & \longrightarrow & \mathrm{PbSO}_{4}
\end{array}
$$

Hal ini disebabkan asam sulfat encer atau sulfat-sulfat yang larut dalam air dapat bereaksi dengan ion $\mathrm{Pb}^{2+}$ membentuk $\mathrm{PbSO}_{4(\mathrm{~s})}$ [10]. Variabel yang digunakan pada penelitian ini adalah $\mathrm{pH}$, yaitu $\mathrm{pH}$ 2, 6, dan 8. Efisiensi terbesar dicapai pada kondisi $\mathrm{pH}$ 8. Pengadukan dilakukan dalam flocculator jar test dengan kecepatan $100 \mathrm{rpm}$ selama 25 menit. Penelitian yang telah dilakukan menunjukkan bahwa air laut mampu menurunkan kandungan $\mathrm{Pb}$ dalam air sumur dari $2 \mathrm{ppm}$ menjadi 0,09 ppm. Berdasarkan persamaan (1) efisiensi penurunan kandungan $\mathrm{Pb}$ dalam air sumur mencapai 95,5\% [10]. Air laut yang ditambahkan pada alum/tawas dapat mengurangi dosis alum yang digunakan dengan tidak menurunkan efisiensi proses removal zat pencemar [11].

\section{Biji Kelor}

Selain air laut, serbuk biji kelor juga bisa dipakai sebagai koagulan alami. Penelitian dengan memanfaatkan serbuk biji kelor dan ekstrak biji kelor telah dilakukan untuk menurunkan kandungan logam $\mathrm{Pb}$ pada limbah cair industri [12]. Proses koagulasi berlangsung optimum pada pH 7-10 [13]. Hasil penelitian menunjukkan bahwa serbuk biji kelor dengan dosis $2 \mathrm{gr} / \mathrm{L}$ mampu menurunkan kandungan logam $\mathrm{Pb}$ dalam air limbah dari 3,5 mg/L menjadi 1,5 mg/L. Sedangkan ekstrak biji kelor dengan dosis $40 \mathrm{~mL} / \mathrm{L}$ mampu menurunkan kandungan logam $\mathrm{Pb}$ dalam air limbah dari 3,5 mg/L menjadi $2 \mathrm{mg} / \mathrm{L}$. Berdasarkan persamaan (1) efisiensi serbuk biji kelor sebesar $57 \%$ dan efisiensi ekstrak biji kelor sebesar $43 \%$. Penelitian dengan memanfaatkan biji kelor sebagai koagulan juga telah dilakukan untuk mengolah air sumur yang mengandung $\mathrm{Pb}[14]$. Variabel yang digunakan dalam penelitian ini adalah konsentrasi biji kelor dalam air. Efisiensi terbesar dicapai pada kondisi dosis serbuk biji kelor 25 gram/100 mL air sumur. Pengadukan dilakukan dalam flocculator jar test dengan kecepatan $100 \mathrm{rpm}$ selama 25 menit. Biji kelor mengandung protein bermuatan positif yang dapat berfungsi sebagai kation polielektrolit. Kation ini akan berikatan dengan anion yang terkandung dalam air sumur sehingga terjadi reaksi displacement (penggantian). Ion $\mathrm{Pb}^{2+}$ dalam air sumur akan berikatan dengan anion yang terkandung dalam biji kelor. Penelitian yang telah dilakukan menunjukkan bahwa serbuk biji kelor mampu menurunkan kandungan $\mathrm{Pb}$ dalam air sumur dari 2,05 menjadi 0,09 ppm. Berdasarkan persamaan (1) efisiensi penurunan kandungan $\mathrm{Pb}$ dalam air sumur mencapai 95,6\% [14].

\section{Eceng Gondok}

Selain air laut dan biji kelor, serbuk eceng gondok juga bisa digunakan sebagai koagulan alami. Penelitian dengan memanfaatkan serbuk eceng gondok teraktivasi $\mathrm{NaOH} 2 \%$ sebagai koagulan telah dilakukan untuk mengolah air sumur yang mengandung $\mathrm{Pb}$ [15]. Variabel yang digunakan pada penelitian ini adalah dosis serbuk eceng gondok dalam air, lama pengadukan, dan lama perendaman proses aktivasi. Efisiensi terbesar dicapai pada kondisi dosis serbuk eceng gondok $800 \mathrm{mg} / 250 \mathrm{~mL}$ air sumur, lama pengadukan 60 menit dengan kecepatan $100 \mathrm{rpm}$, dan lama perendaman serbuk eceng gondok dalam $\mathrm{NaOH} 2 \%$ selama 24 jam. Eceng gondok mengandung selulosa yang mempunyai gugus $-\mathrm{OH}$ dan $-\mathrm{CH}$ [15]. Gugus ini akan bereaksi dengan ion $\mathrm{Pb}^{2+}$ yang terkandung dalam air sumur. Penelitian yang telah dilakukan menunjukkan bahwa serbuk eceng gondok mampu menurunkan kandungan $\mathrm{Pb}$ dalam air sumur dari $2 \mathrm{ppm}$ menjadi 0,08 ppm. Berdasarkan persamaan (1) efisiensi penurunan kandungan $\mathrm{Pb}$ dalam air sumur mencapai $96 \%[16]$.

\section{Koagulasi Menggunakan Koagulan Kimiawi}

Selain koagulan alami, koagulan kimiawi jugai telah diteliti untuk menurunkan kandungan logam $\mathrm{Pb}$. Ion $\mathrm{Pb}^{2+}$ yang terdapat dalam air bisa dihilangkan dengan koagulan yang mengandung anion sehingga diharapkan ion $\mathrm{Pb}^{2+}$ akan berikatan dengan anion dalam koagulan. Koagulan kimiawi yang sudah diteliti antara lain alum/tawas dan $\mathrm{FeCl}_{3}$. 


\section{Koagulan Alum/Tawas}

Basra, S.M.A., et al. pada tahun 2014 melakukan penelitian dengan memanfaatkan alum untuk menurunkan kandungan logam $\mathrm{Pb}$ pada limbah cair industri. Proses koagulasi dan adsorpsi berlangsung optimum pada $\mathrm{pH}$ 5-8 [17]. Hasil penelitian menunjukkan bahwa alum dengan dosis $20 \mathrm{mg} / \mathrm{L}$ mampu menurunkan kandungan logam $\mathrm{Pb}$ dalam air limbah dari 3,5 mg/L menjadi 2,25 $\mathrm{mg} / \mathrm{L}$. Berdasarkan persamaan (1) efisiensi alum sebesar 36\%. Sidni, dkk.(2012) melakukan penelitian dengan memanfaatkan alum dengan rumus kimia $\mathrm{Al}_{2}\left(\mathrm{SO}_{4}\right) \cdot 18 \mathrm{H}_{2} \mathrm{O}$ sebagai koagulan untuk mengolah air lindi Tempat Pembuangan Akhir (TPA) Jatibarang di Semarang yang mengandung $\mathrm{Pb}$. Varibel yang digunakan dalam penelitian ini adalah dosis alum. Efisiensi terbesar dicapai pada kondisi dosis alum $1250 \mathrm{mg} / \mathrm{L}$. Pengadukan dilakukan dalam flocculator jar test dengan kecepatan $100 \mathrm{rpm}$ selama 5 menit untuk proses koagulasi dan dilanjutkan pengadukan dengan kecepatan $60 \mathrm{rpm}$ selama 15 menit untuk proses flokulasi . Ion $\mathrm{Pb}^{2+}$ dalam air sumur akan berikatan dengan anion $\mathrm{SO}_{4}{ }^{2-}$ yang terkandung dalam alum. Penelitian yang telah dilakukan menunjukkan bahwa alum mampu menurunkan kandungan $\mathrm{Pb}$ dalam air lindi dari 0,3 ppm menjadi $0,1 \mathrm{ppm}$. Berdasarkan persamaan (1) efisiensi penurunan kandungan $\mathrm{Pb}$ dalam air sumur mencapai $67 \%[18]$.

\section{Koagulan $\mathrm{FeCl}_{3}$}

Selain meneliti alum, Sidni, I., dkk. pada tahun 2012 juga melakukan penelitian dengan memanfaatkan $\mathrm{FeCl}_{3}$ sebagai koagulan untuk mengolah air lindi TPA Jatibarang di Semarang yang mengandung $\mathrm{Pb}$. Varibel yang digunakan dalam penelitian ini adalah dosis $\mathrm{FeCl}_{3}$. Efisiensi terbesar dicapai pada kondisi dosis $\mathrm{FeCl}_{3} 1000 \mathrm{mg} / \mathrm{L}$. Pengadukan dilakukan dalam flocculator jar test dengan kecepatan $100 \mathrm{rpm}$ selama 5 menit untuk proses koagulasi dan dilanjutkan pengadukan dengan kecepatan $60 \mathrm{rpm}$ selama 15 menit untuk proses flokulasi . Ion $\mathrm{Pb}^{2+}$ dalam air sumur akan berikatan dengan anion $\mathrm{Cl}^{-}$yang terkandung dalam alum. Penelitian yang telah dilakukan menunjukkan bahwa $\mathrm{FeCl}_{3}$ mampu menurunkan kandungan $\mathrm{Pb}$ dalam air lindi dari 0,3 ppm menjadi 0,05 ppm. Berdasarkan persamaan (1) efisiensi penurunan kandungan $\mathrm{Pb}$ dalam air sumur mencapai $84 \%$ [18]. Koagulan $\mathrm{FeCl}_{3}$ juga mampu menurunkan kandungan zat pencemar dengan baik sehingga air hasil olahan memenuhi syarat untuk diproses dengan sistem membran [19].

Penelitian-penelitian yang telah dilakukan untuk menghilangkan kandungan $\mathrm{Pb}$ dalam air dengan metode koagulasi dapat dilihat pada Tabel 6.

Tabel 6. Efisiensi removal $\mathrm{Pb}$ beberapa koagulan

\begin{tabular}{llcc}
\hline \multicolumn{1}{c}{ Koagulan } & Air yang diolah & Efisiensi removal $\mathrm{Pb}(\%)$ & Sumber \\
\hline \hline Air laut & air sumur & $96 \%$ & {$[8]$} \\
Serbuk biji kelor & air sumur & $96 \%$ & {$[14]$} \\
Serbuk eceng gondok & air sumur & $96 \%$ & {$[16]$} \\
teraktivasi NaOH 2\% & & & \\
Alum $20 \mathrm{mg} / \mathrm{L}$ & limbah industri & $36 \%$ & {$[12]$} \\
Alum $1250 \mathrm{mg} / \mathrm{L}$ & air lindi TPA & $67 \%$ & {$[18]$} \\
$\mathrm{FeCl} 31000 \mathrm{mg} / \mathrm{L}$ & air lindi TPA & $84 \%$ & {$[18]$} \\
\hline \hline
\end{tabular}

Berdasarkan Tabel 6 dapat diketahui bahwa untuk menghilangkan kandungan $\mathrm{Pb}$ dalam air sumur, koagulan alami serbuk eceng gondok teraktivasi $\mathrm{NaOH} 2 \%$ mempunyai efisiensi paling tinggi, yaitu 96\%. Sedangkan untuk koagulan kimiawi, $\mathrm{FeCl}_{3}$ dosis $1000 \mathrm{mg} / \mathrm{L}$ memiliki efisiensi lebih bagus dari tawas, yaitu $84 \%$.

Kandungan logam $\mathrm{Pb}$ pada sampel air sumur mengandung logam $\mathrm{Pb}$ antara 0,15 sampai $0,23 \mathrm{mg} / \mathrm{L}$, sedangkan batas maksimum yang diperbolehkan $0,05 \mathrm{mg} / \mathrm{L}$. Berdasarkan persamaan (1), kemampuan setiap koagulan menghilangkan kandungan logam $\mathrm{Pb}$ dalam lima sampel air sumur dapat dilihat pada Gambar 2 sampai Gambar 6. 


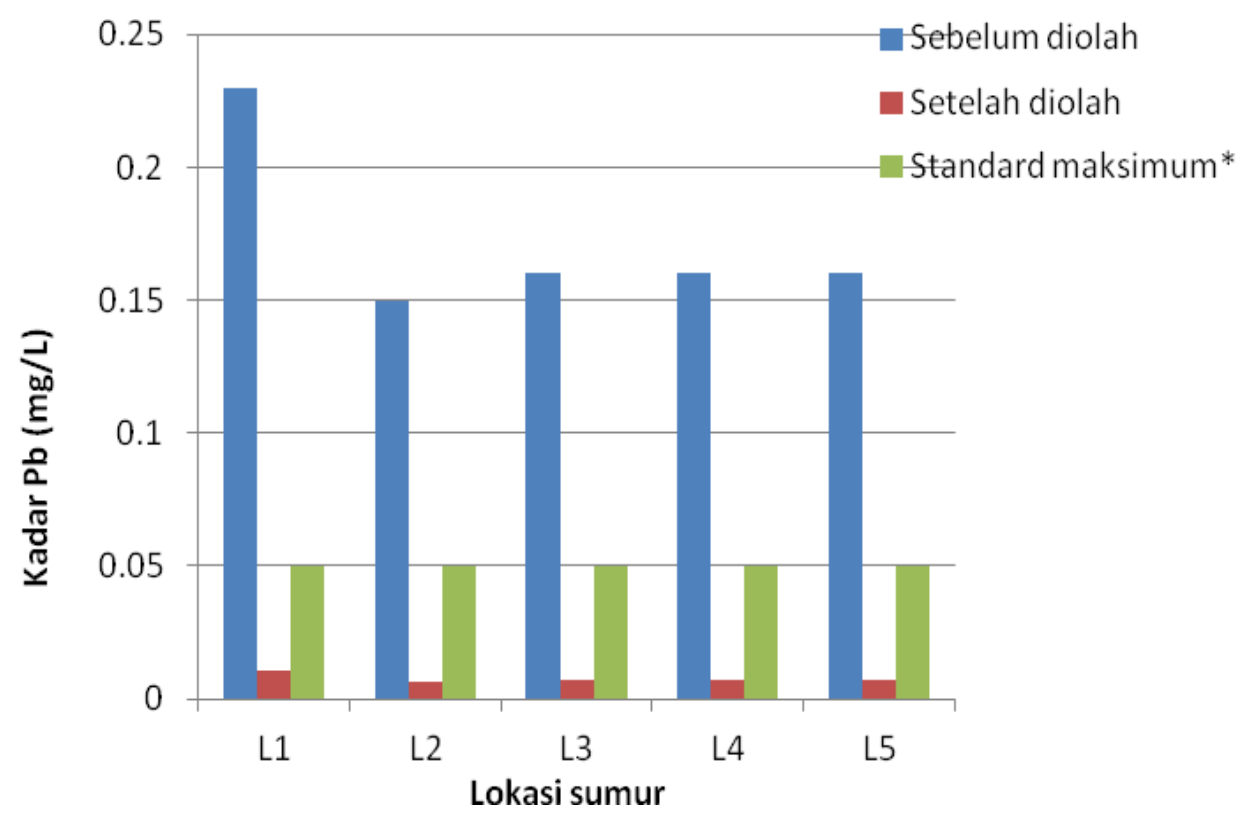

Gambar 2. Kandungan $\mathrm{Pb}$ pada 5 sampel air sumur sebelum dan setelah diolah menggunakan koagulan air laut dibandingkan dengan standard maksimum.

Gambar 2 menunjukkan bahwa pengolahan air sumur menggunakan koagulan air laut menghasilkan air yang sudah memenuhi standard air bersih. Lima sampel air sumur yang mengandung $\mathrm{Pb} 0,15 \mathrm{mg} / \mathrm{L}$ sampai $0,23 \mathrm{mg} / \mathrm{L}$ bisa diolah menjadi air bersih yang mengandung $\mathrm{Pb}$ $0,0072 \mathrm{mg} / \mathrm{L}$ sampai $0,01035 \mathrm{mg} / \mathrm{L}$. Air hasil olahan mengandung kadar $\mathrm{Pb}$ di bawah standard maksimum yang dipersyaratkan untuk air bersih [2].

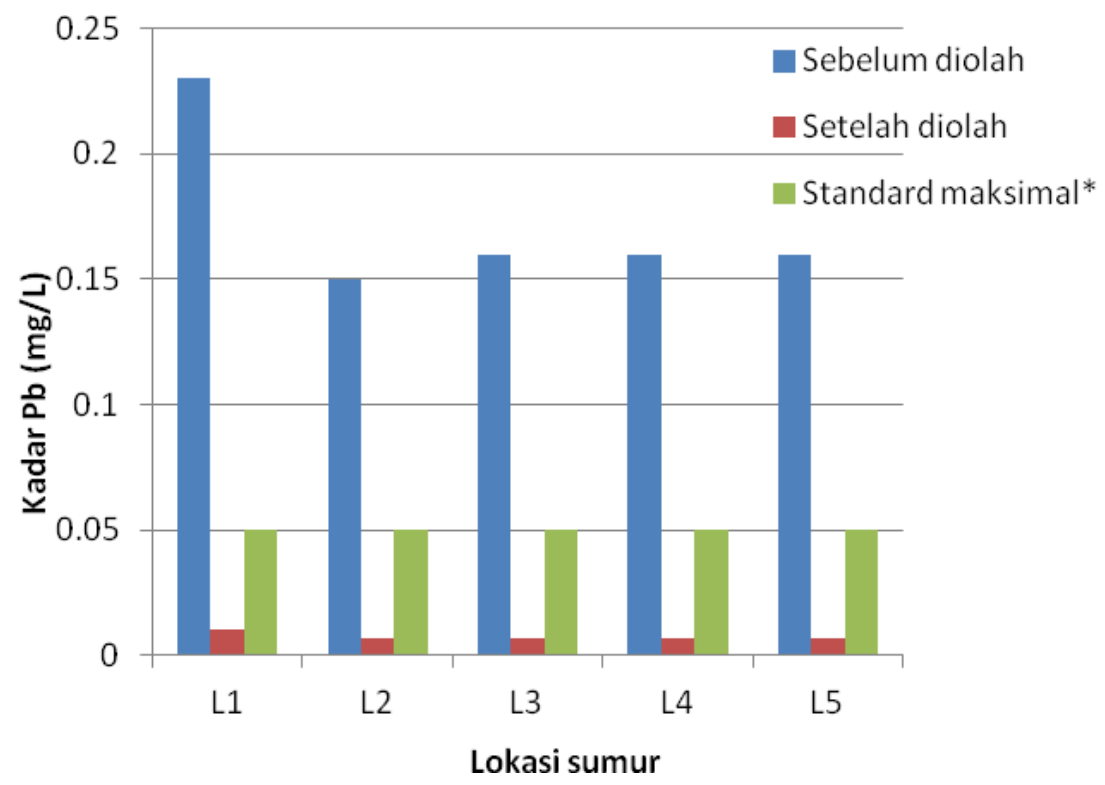

Gambar 3. Kandungan $\mathrm{Pb}$ pada 5 sampel air sumur sebelum dan setelah diolah menggunakan koagulan serbuk biji kelor dibandingkan dengan standard maksimum.

Gambar 3 menunjukkan bahwa pengolahan air sumur menggunakan koagulan serbuk biji kelor menghasilkan air yang sudah memenuhi standard air bersih. Lima sampel air sumur yang mengandung $\mathrm{Pb} 0,15 \mathrm{mg} / \mathrm{L}$ sampai $0,23 \mathrm{mg} / \mathrm{L}$ bisa diolah menjadi air bersih yang mengandung $\mathrm{Pb}$ 
0,00704 mg/L sampai 0,01012 mg/L. Air hasil olahan mengandung kadar $\mathrm{Pb}$ di bawah standard maksimum yang dipersyaratkan untuk air bersih [2].

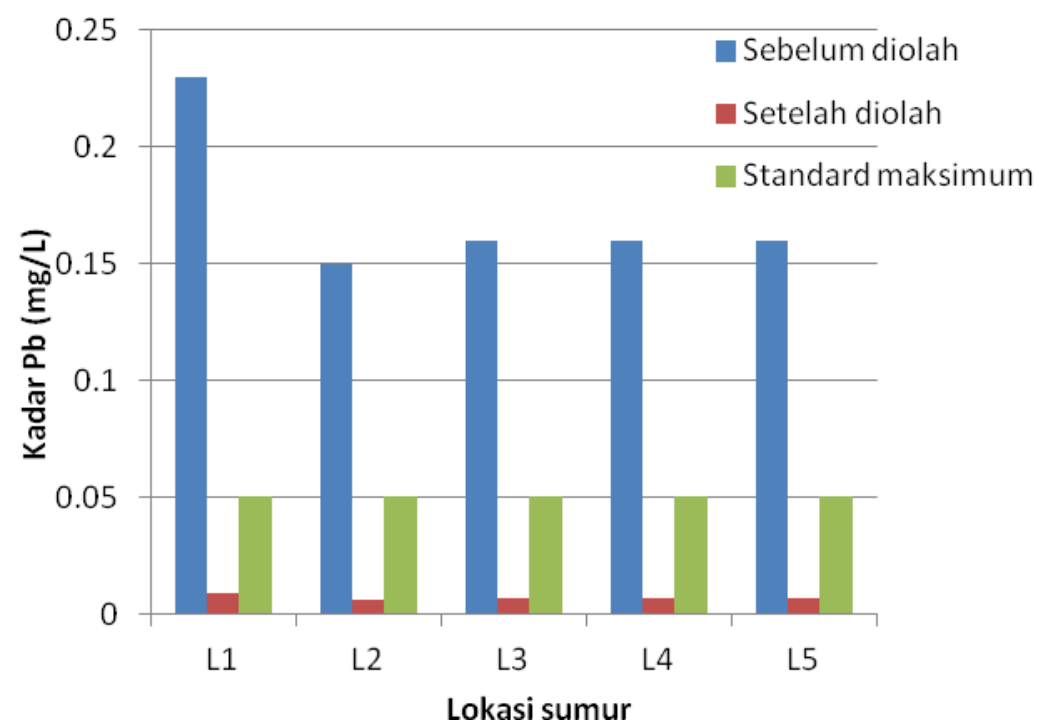

Gambar 4. Kandungan $\mathrm{Pb}$ pada 5 sampel air sumur sebelum dan setelah diolah menggunakan koagulan serbuk eceng gondok teraktivasi $\mathrm{NaOH} 2 \%$ dibandingkan dengan standard maksimum.

Gambar 4 menunjukkan bahwa pengolahan air sumur menggunakan koagulan serbuk eceng gondok teraktivasi $\mathrm{NaOH} 2 \%$ sudah memenuhi standard air bersih. Lima sampel air sumur yang mengandung $\mathrm{Pb} 0,15 \mathrm{mg} / \mathrm{L}$ sampai $0,23 \mathrm{mg} / \mathrm{L}$ bisa diolah menjadi air bersih yang mengandung $\mathrm{Pb} 0,0064 \mathrm{mg} / \mathrm{L}$ sampai $0,0092 \mathrm{mg} / \mathrm{L}$. Air hasil olahan mengandung kadar $\mathrm{Pb} \mathrm{di}$ bawah standard maksimum yang dipersyaratkan untuk air bersih [2].

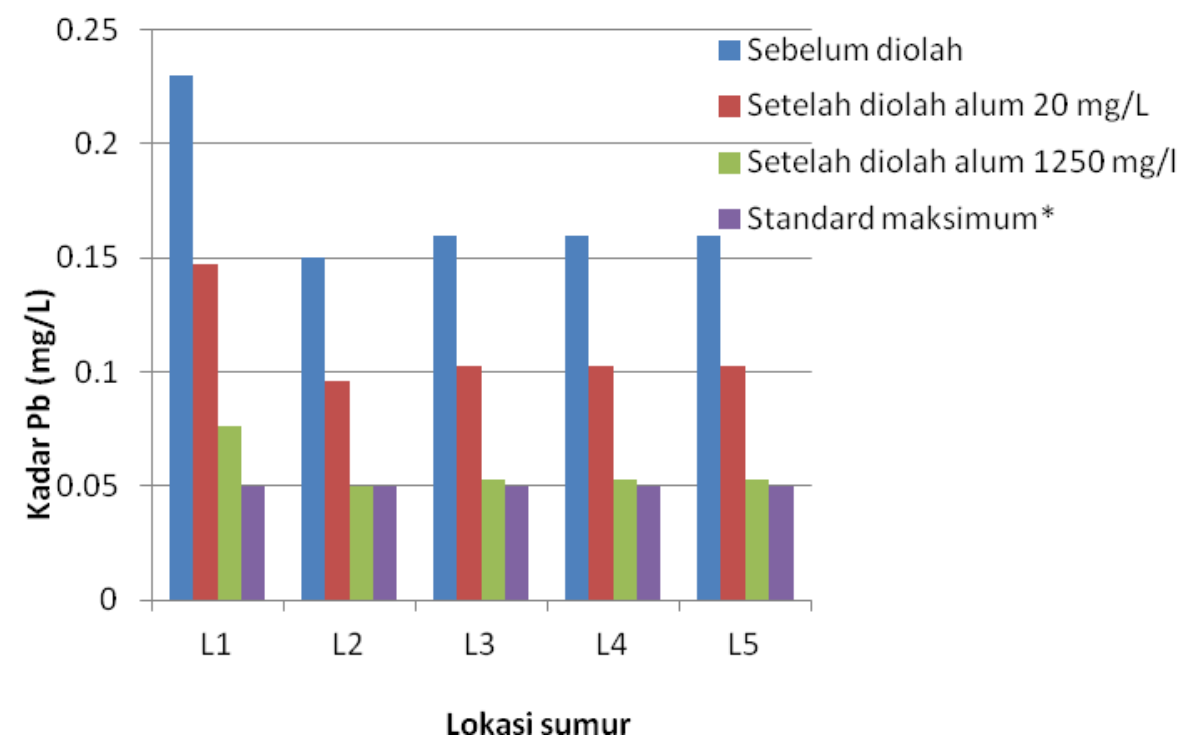

Gambar 5. Kandungan $\mathrm{Pb}$ pada 5 sampel air sumur sebelum dan setelah diolah menggunakan koagulan alum $20 \mathrm{mg} / \mathrm{L}$ dan koagulan alum $1250 \mathrm{mg} / \mathrm{L}$ dibandingkan dengan standard maksimum.

Gambar 5 menunjukkan bahwa pengolahan air sumur menggunakan koagulan alum 20 $\mathrm{mg} / \mathrm{L}$ dan alum $1250 \mathrm{mg} / \mathrm{L}$ belum memenuhi standard air bersih. Lima sampel air sumur yang mengandung $\mathrm{Pb} 0,15 \mathrm{mg} / \mathrm{L}$ sampai $0,23 \mathrm{mg} / \mathrm{L}$ bisa diolah dengan alum $20 \mathrm{mg} / \mathrm{L}$ menjadi air yang mengandung $\mathrm{Pb} 0,096 \mathrm{mg} / \mathrm{L}$ sampai $0,1472 \mathrm{mg} / \mathrm{L}$. Sedangkan air sumur bila diolah dengan alum $1250 \mathrm{mg} / \mathrm{L}$ menghasilkan air yang mengandung $\mathrm{Pb} 0,0495 \mathrm{mg} / \mathrm{L}$ sampai $0,0759 \mathrm{mg} / \mathrm{L}$. Air hasil 
olahan yang dihasilkan menggunakan alum $20 \mathrm{mg} / \mathrm{L}$ maupun $1250 \mathrm{mg} / \mathrm{L}$ masih mengandung kadar $\mathrm{Pb}$ di atas standard maksimum yang dipersyaratkan untuk air bersih sehingga belum memenuhi syarat air bersih [2].

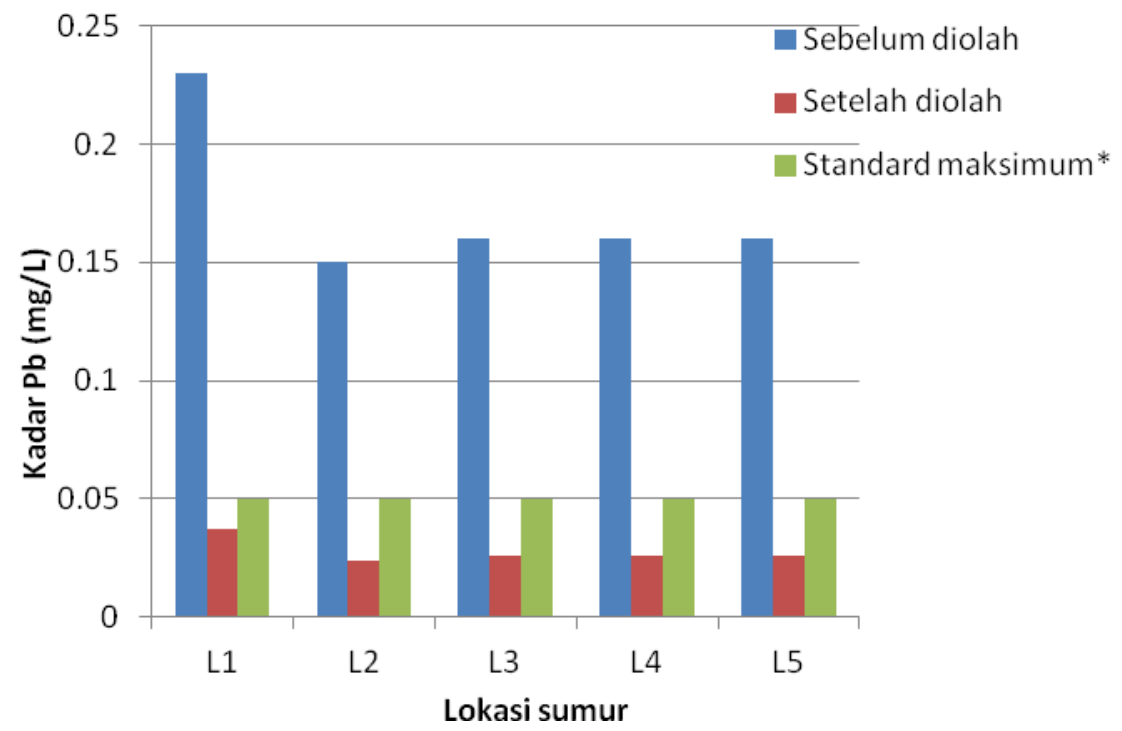

Gambar 6. Kandungan $\mathrm{Pb}$ pada 5 sampel air sumur sebelum dan setelah diolah menggunakan koagulan $\mathrm{FeCl}_{3} 1000$ mg/L dibandingkan dengan standard maksimum

Gambar 6 menunjukkan bahwa pengolahan air sumur menggunakan koagulan $\mathrm{FeCl}_{3} 1000$ $\mathrm{mg} / \mathrm{L}$ sudah memenuhi standard air bersih. Lima sampel air sumur yang mengandung $\mathrm{Pb} 0,15 \mathrm{mg} / \mathrm{L}$ sampai $0,23 \mathrm{mg} / \mathrm{L}$ bisa diolah menjadi air bersih yang mengandung $\mathrm{Pb} 0,024 \mathrm{mg} / \mathrm{L}$ sampai 0,0368 $\mathrm{mg} / \mathrm{L}$. Air hasil olahan mengandung kadar $\mathrm{Pb}$ di bawah standard maksimum yang dipersyaratkan untuk air bersih [2].

Berdasarkan Gambar 2 sampai Gambar 6, koagulan air laut, serbuk biji kelor, serbuk eceng gondok teraktivasi $\mathrm{NaOH} 2 \%$, dan $\mathrm{FeCl}_{3} 1000 \mathrm{mg} / \mathrm{L}$ dapat digunakan untuk mengolah air sumur menjadi air bersih. Mengenai pemilihan jenis koagulan bisa dikembalikan ke masyarakat kembali. Penerapan metode koagulasi untuk mengolah air sumur memerlukan percontohan pilot project sehingga masyarakat yakin untuk melakukan pengolahan ini. Apabila air hasil olahan masih berbau atau berasa bisa dilanjutkan dengan pengolahan menggunakan karbon aktif.

\section{KESIMPULAN}

Koagulan yang dapat digunakan untuk mengolah 5 sampel air sumur mengandung logam $\mathrm{Pb}$ sebesar $0,15 \mathrm{mg} / \mathrm{L}$ sampai $0,23 \mathrm{mg} / \mathrm{L}$ menjadi air bersih adalah air laut, biji kelor, serbuk eceng gondok teraktivasi $\mathrm{NaOH} 2 \%$, dan $\mathrm{FeCl}_{3} 1000 \mathrm{mg} / \mathrm{L}$. Koagulan yang mempunyai efisiensi tertinggi adalah serbuk eceng gondok teraktivasi $\mathrm{NaOH} 2 \%$, yaitu sebesar $96 \%$. Selanjutnya efisiensi serbuk biji kelor mencapai 95,6\%, air laut 95,5\%, dan $\mathrm{FeCl}_{3} 1000 \mathrm{mg} / \mathrm{L} 84 \%$. Koagulan alum dapat mereduksi kadar $\mathrm{Pb}$ dalam 5 sampel air sumur, alum $20 \mathrm{mg} / \mathrm{L}$ mencapai $36 \%$ dan alum $1250 \mathrm{mg} / \mathrm{L}$ mencapai $67 \%$, namun demikian hasil olahan menggunakan koagulan alum belum memenuhi standard air bersih.

\section{DAFTAR PUSTAKA}

[1] Anonim (2015), Identifikasi Kualitas Air Bersih Pada Kawasan Padat Penduduk Kota Pasuruan, Dinas Pekerjaan Umum Cipta Karya dan Tata Ruang Provinsi Jawa Timur.

[2] Anonim (1990), PERMENKES Nomor 416/MENKES/PER/IX/1990.

[3] Widowati, W., Sastiono, A., dan Jusuf, R. (2008), Efek Toksik Logam, Penerbit Andi, Yogyakarta. 
[4] Moelyaningrum,A.D. (2009), Hubungan Kadar Timbal Darah dengan Kejadian Osteoporosis Pada Wanita Post Menopause di Surabaya, Universitas Airlangga.

[5] Palar, H. (1994), Pencemaran dan Toksikologi Logam Berat. Penerbit Rineka Cipta, Jakarta.

[6] Said, N.I. (2010), Metoda Penghilangan Logam Berat (As, Cd, Cr, Ag, Cu, Pb, Ni dan Zn) di Dalam Air Limbah Industri, Pusat Teknologi Lingkungan, BPPT, JAI Vol. 6, No. 2.

[7] Soliman, A.M., Elwy, H.M., Thiemann, T., Majedi, Y., Labata, F.T., Al-Rawashdeh, N.A.F. (2016), "Removal of $\mathrm{Pb}$ (II) Ions from Aqueous Solutions by Sulphuric Acid-Treated Palm Tree Leaves", Journal of The Taiwan Institute of Chemical Engineers, Vol. 58, pp. 264-273.

[8] Permana, R.L., Miswadi, S.S., Santosa, N.B. (2014), "Penggunaan Air Laut sebagai Koagulan untuk Menurunkan Kadar $\mathrm{Pb}$ dan Intensitas Warna", Indonesian Journal of Chemical Science, Vol. 3, No. 2.

[9] Wilasih, T. (2008), "Penurunan BOD dan COD Limbah Kertas dengan Air Laut sebagai Koagulan", Jurnal Rekayasa Perencanaan, Vol. 4, No. 2, hal. 5-8.

[10] Vogel's (1979), Textbook of Macro and Semimicro Qualitative Inorganic Analysis, Fifth edition, Richard Clay (The Chaucer Press) Ltd, Bungay, Suffolk.

[11] Harfouchi, H., Hank, D., Hella, A. (2016), "Response Surface Methodology for The Elimination of Humic Subtances from Water by Coagulation Using Powdered Saddled Sea Bream Scale as Coagulant-aid", Process Safety and Environmental Protection, Vol. 99, pp. 216-226.

[12] Basra, S.M.A., Iqbal, Z., Khalil-ur-Rehman, Hafez-Ur-Rehman, Ejaz, M.F. (2014), "Time Course Changes in $\mathrm{pH}$, Electrical Conductivity and Heavy Metals $(\mathrm{Pb}, \mathrm{Cr})$ of Wastewater Using Moringa Oleifera Lam, Seed and Alum, a Comparative Evaluation", Journal of Applied Research and technology, Vol. 12, Issue 3, pp. 560-567.

[13] Wei, N., Zhang, Z., Liu, D., Wu, Y., Wang, J., Wang., Q. (2015), "Coagulation Behavior of Polyaluminium Chloride: Effects of $\mathrm{pH}$ and Coagulant Dosage", Chinese Journal of Chemical Engineering, Vol. 23, Issue 6, pp.1041-1046.

[14] Nugroho, B.A., Miswadi, S.S., Santosa, N.B. (2014), "Penggunaan Serbuk Biji Kelor untuk Menurunkan Kadar $\mathrm{Pb}$ dan Intensitas Warna", Indonesian Journal of Chemical Science, Vol. 3, No.3.

[15] Thiripura, M., Ramesh, Atmakuru (2012), "Isolation and Charactherization of Cellulose Nanofibers from The Equatic Weed Water Hyacinth - Eichornia Crassipes", Journal of Charbohydrate and Polymers, Vol. 87, pp. 1701-1705.

[16] Wibawa, I.G.P., Sedyawati, S.M.R., dan Sumarni, W. (2014), "Aktivasi Serbuk Eceng Gondok (Eichornia Crassipes) untuk Menurunkan Kadar Ion Timbal $\left(\mathrm{Pb}^{2+}\right)$ dalam Air Sumur Gali di TPA Jatibarang Semarang”, Indonesian Journal of Chemical Science, Vol. 3, No. 3.

[17] Vieira, A.M.S., Vieira, M.F., Silva, G.F., Araujo, A.A., Marcia R., Fagundes-Klen, Marcia, T.V., Bergamasco, R. (2010), "Use of Moringa Oleifera Seed as A Natural Adsorbent for Wastewater Treatment", Water Air Soil Pollut, Vol. 206, pp. 273 - 281.

[18] Irvan Sidni (2012), Penurunan Konsentrasi Timbal dan Krom dari Air Lindi dengan Pemanfaan Alum dan Ferri Klorida sebagai Koagulan Melalui Proses Koagulasi dan Flokulasi (Studi Kasus : Air Lindi TPA Jati Barang), Tesis, Universitas Diponegoro.

[19] Ang, W.L., Mohammad, A.W., Teow, Y.H., Benamor, A., Hilal, N., (2015), "Hybrid Chitosan/ $\mathrm{FeCl}_{3}$ Coagulation-Membrane Processes: Performance Evaluation and membrane Fouling Study in Removing Natural Organic Matter", Separation and Purification Technology, Vol. 52, pp. 23-31. 